\title{
Novel of chronic phase of Canine Uveodermatologic Syndrome (Vogt- Koyanagi-Harada-like syndrome)
}

\author{
Yesari ERÖKSÜZ ${ }^{1}$, R. Richard DUBIELZIG ${ }^{2}$ \\ ${ }^{1}$ Firat University, Veterinary Medical School, Pathology Department, Elazı $\breve{g} / T U R K E Y ;{ }^{2}$ Wisconsin University, Veterinary Medical \\ School, Pathology Department, WI/ USA.
}

\begin{abstract}
Summary: The aim of the present study is to evaluate morphological findings of chronic uveodermatologic syndrome (UDS) in dogs. Five canine cases which had been diagnosed as chronic form of canine UDS pathologically were re-evaluated for histopathologically and immunohistochemically (CD3 and CD20). The dogs were from different breeds with the mean of 6-year-old (range 3 to 12 years) and enucleated globes were submitted from the different animal hospitals with the history of bilateral uveitis that was uncontrollable with anti-inflammatories, followed by glaucoma and blindness. Microscopically; mild to moderate lymphoplasmacytic uveitis together with histiocytic pigment phagocytosis, melanin containing macrophage infiltration and epithelial depigmentation were the main findings detected. Secondary glaucoma, synechia and iris bombé were also seen. The B lymphocytes were predominantly found in affected parts of the globe including iris, ciliary body, cilliary process and choroid. In conclusion, the chronic phase of canine uveodermatologic syndrome is characterized by mild to moderate lymphoplasmacytic uveitis or panuveitis. Although chronic form has not been reported in earlier canine reports, it is compatible with the chronic form of Vogt-KoyanagiHarada cases in humans.
\end{abstract}

Key words: Chronic phase, dog, histopathology, immunohistochemistry, Uveodermatologic Syndrome, Vogt-Koyanagi-Harada like Syndrome.

\section{Köpeklerin Uveodermatolojik Sendromunda (Vogt-Koyanagi-Harada Benzeri Sendrom) kronik dönem lezyonları}

Özet: Bu çalışmada köpeklerin uveodermatolojik sendromunun kronik formundaki morfolojik bulgular sunuldu. Daha önce patolojik olarak kronik Uveodermatolojik Sendrom (UDS) tanısı konmuş, ortalama 6 yaşında (3-12 yaş), 5 adet köpeğe ait 6 adet göz dokusu histopatolojik ve immünohistokimyasal (CD3 ve CD20) olarak incelendi. Enükle edilen gözler farklı hayvan hastanelerinden gönderilmiş olup, anemnez bulgusu olarak anti-inflamatuar ilaçlarla kontrol edilemeyen bilateral uveitis, glakom ve körlük bulguları mevcuttu. Hafif-orta şiddette uveitisle birlikte histiositik pigment fagositozu, melanin içeren makrofaj infiltrasyonu ve siliar epitelde depigmentasyon gözlenen belli başlı bulgulardı. Sekonder glakom, sineşi ve iris bombe bulgularına da rastlandı. Gözdeki incelenen yapılarda (iris, korpus siliare stroması, prosesus siliaris) B lenfositlerin baskın olarak bulunduğu ortaya kondu. Sonuç olarak, kronik dönem uveodermatolojik sendrom da hafif-orta şiddette uveitisle karakterizedir. Bu bulgu, daha önce köpeklerde bildirilmemiş olmakla birlikte insanlardaki kronik Vogt-Koyanagi-Harada sendromuyla uyumludur.

Anahtar sözcükler: Histopatoloji, immunohistokimya, köpek, kronik dönem, Uveodermatolojik Sendrom, Vogt-KoyanagiHarada Benzeri Sendrom.

\section{Introduction}

Canine uveodermatologic syndrome is an autoimmuneinflammatory disease targeting melanine or a melanocytic protein component in the eyes, skin and mucous membranes (6). As it resembles morphologically the human condition known as Vogt-Koyanagi-Harada (VKH) syndrome, it is also called as VKH-like syndrome $(6,14)$. However, there are some differences in clinical presentation with regard to multisystemic involvement $(12,14)$. Although generally considered to be more common in Akitas and in other Northern breeds, there have been reports of the disease in a wide range of dog breeds $(2-5,7,9)$.
The classical canine cases of the syndrome has been histologically characterized by non-necrotic granulomatous uveitis causing bilateral thickening of the uvea, scattered melanin pigment, bilateral involvement and relative absence of inflammatory changes in retina (2-7, 9-12). The diagnosis of chronic form of VKH was based on lymphoplasmacytic uveitis, evidence of melanin containing macrophages, pigment clumping, pigment incontinence, depigmentation of epithelial cells and bilateral involvement of the eyes. No information is available relating with the histological lesions of chronic stages or milder form of the disorder in dogs. 
The aim of this report is to present morphological and immuno-histochemical findings in 6 canine globes diagnosed as chronic phase of UDS in 5 dogs.

\section{Materials and Methods}

Five canine cases averaging 6-year-old which were diagnosed histopathologically as chronic form of canine UDS from Comparative Ocular Pathology Laboratory of Wisconsin collection were used for this study. The globes were fixed in $10 \%$ neutral buffered formalin, sectioned in sagittal plane, processed routinely and embedded in paraffin blocks. Sections of the globes were stained with hematoxylin and eosin (H\&E). The slides, submission forms and original reports were reviewed for relevant information. The archival blocks of the globes were selected and re-evaluated for histopathologic changes and lymphocytic phenotype by immunohistochemistry. The immunohistochemical staining for the expression of the CD20 and CD3 was performed using avidine-biotine peroxidase technique. Appropriate positive (normal canine lymph node) and negative controls were used by using 3, 3' diaminobenzidine as chromogen. Negative controls were processed in the same way, using buffer solution in place of the primary antibody. Monoclonal antibodies for CD3 (anti-mouse Dako-M7254, 1:200 dilution) and anti-rabbit CD20 (Fisher RB9013P, 1:400 dilution) were used in automated stainer (Lab Vision 720 2 D).

\section{Results}

The enucleated globes were submitted from the different animal hospitals with a history of bilateral uveitis that was uncontrollable topical and systemic antiinflammatories (prednisone, timolol- $0.5 \%$ solution, atropine and hydrochlortiazidine) and followed by glaucoma and blindness (Table-1). According to the history, none of the animals showed any systemic illness. None of the dogs had a history of eye trauma or intraocular surgery, and there were no abnormalities in serum chemistry. There was bilateral involvement in all the cases. The cases (2, 3 and 5) were enucleated unilaterally, case 4 was enucleated bilaterally and case one was the second eye from a dog that had been enucleated one year before. Clinically; only one dog (Case 4) was suspected from UDS.

Case 1: Case 1 was female-spayed, 5-year-old, Dachshund dog. The right eye had been enucleated 1 year ago and showing clinically and histologically uveitis, retinal detachment, hyphema and corneal ulcer.

The referring veterinarian reported the anterior uveitis that was uncontrollable with the treatment, shallow chamber and increased pigment in tapetum. The duration of the problem for the left eye was about 2 months. Clinical tentative diagnosis was asymmetric uveitis.

Histologically; moderate, chronic lymphoplasmacytic anterior uveitis was detected. There was also moderate
Table 1:Breed, age-sex, history and clinical diagnosis in the dogs.

Tablo 1: Köpeklerde yaş, cinsiyet, anemnez ve klinik tanı bilgileri.

\begin{tabular}{|c|c|c|c|c|}
\hline $\begin{array}{l}\text { Case } \\
\text { Number }\end{array}$ & Breed & Age/Sex & $\begin{array}{c}\text { Duration } \\
\text { of } \\
\text { Illness }\end{array}$ & Clinical Diagnosis \\
\hline 1 & Dachshund & $\begin{array}{l}5 \text { y old } \\
\text { FS }\end{array}$ & 8 months & $\begin{array}{l}\text { Chronic anterior } \\
\text { uveitis }\end{array}$ \\
\hline 2 & Mixed & $\begin{array}{l}3 \text { y old } \\
\text { MN }\end{array}$ & 8 weeks & $\begin{array}{l}\text { Chronic bilateral } \\
\text { uveitis } \\
\text { Secondary } \\
\text { glaucoma }\end{array}$ \\
\hline 3 & $\begin{array}{l}\text { Labrador } \\
\text { retriever }\end{array}$ & $\begin{array}{l}12 \text { y old } \\
\text { FS }\end{array}$ & 8 weeks & $\begin{array}{l}\text { Anterior uveitis } \\
\text { Glaucoma }\end{array}$ \\
\hline 4 & $\begin{array}{l}\text { Labrador } \\
\text { retriever }\end{array}$ & $\begin{array}{l}7 \text { y old } \\
\text { FS }\end{array}$ & $\begin{array}{l}24 \\
\text { months }\end{array}$ & $\begin{array}{l}\text { Chronic panuveitis } \\
\text { Secondary } \\
\text { glaucoma } \\
\text { Uveodermatologic } \\
\text { syndrome? }\end{array}$ \\
\hline 5 & $\begin{array}{l}\text { Australian } \\
\text { shepherd }\end{array}$ & $\begin{array}{l}3 \text { y old } \\
\text { MN }\end{array}$ & 3 weeks & $\begin{array}{l}\text { Chronic moderate } \\
\text { panuveitis } \\
\text { Secondary } \\
\text { glaucoma }\end{array}$ \\
\hline
\end{tabular}

FS: Female Spayed

MN: Male Neutralized

lymphoplasmacytic and mild histiocytic choroiditis causing thickening of the pigmented choroid. The most prominent change was histiocyte rich pigment phagocytosis in anterior uvea. The melanophages that were aggregated in clustered and heavily pigmented were present throughout the uvea. The row state location of melanophages under the variably depigmented ciliary epithelial cells was remarkable (Fig-1A). There was also variable pigment dispersion amongst the melanophages in processus ciliaris and corpus ciliare. Plump melanophages clusturing interrupted by inflammatory infiltrations and pigment dispersion were most prevalent in choroid (Fig-1B). Broad posterior synechia with a forward bowing of iris tissue causing iris bombé was detected. There was an anterior synechia characterized by thin preiridial fibrovascular membrane. The retina contained adequate number of ganglion cells and the optic nerve was within normal limits.

Case 2: Case 2 was 3-year-old, mixed breed, castrated male dog. The referring veterinarian reported chronic bilateral uveitis and secondary glaucoma of undetermined cause at initial presentation. The duration for the problem was about 8 weeks. The left eye has retained limited vision, and the left fundus was normal. As the right eye caused discomfort with high intraocular pressure (80 mmHg, Reference Interval: $15-25 \mathrm{~mm} \mathrm{Hg}$ ), it was enucleated.

Histopathologically; chronic lymphoplasmacytic panuveitis was detected. The infiltrate was mild in 


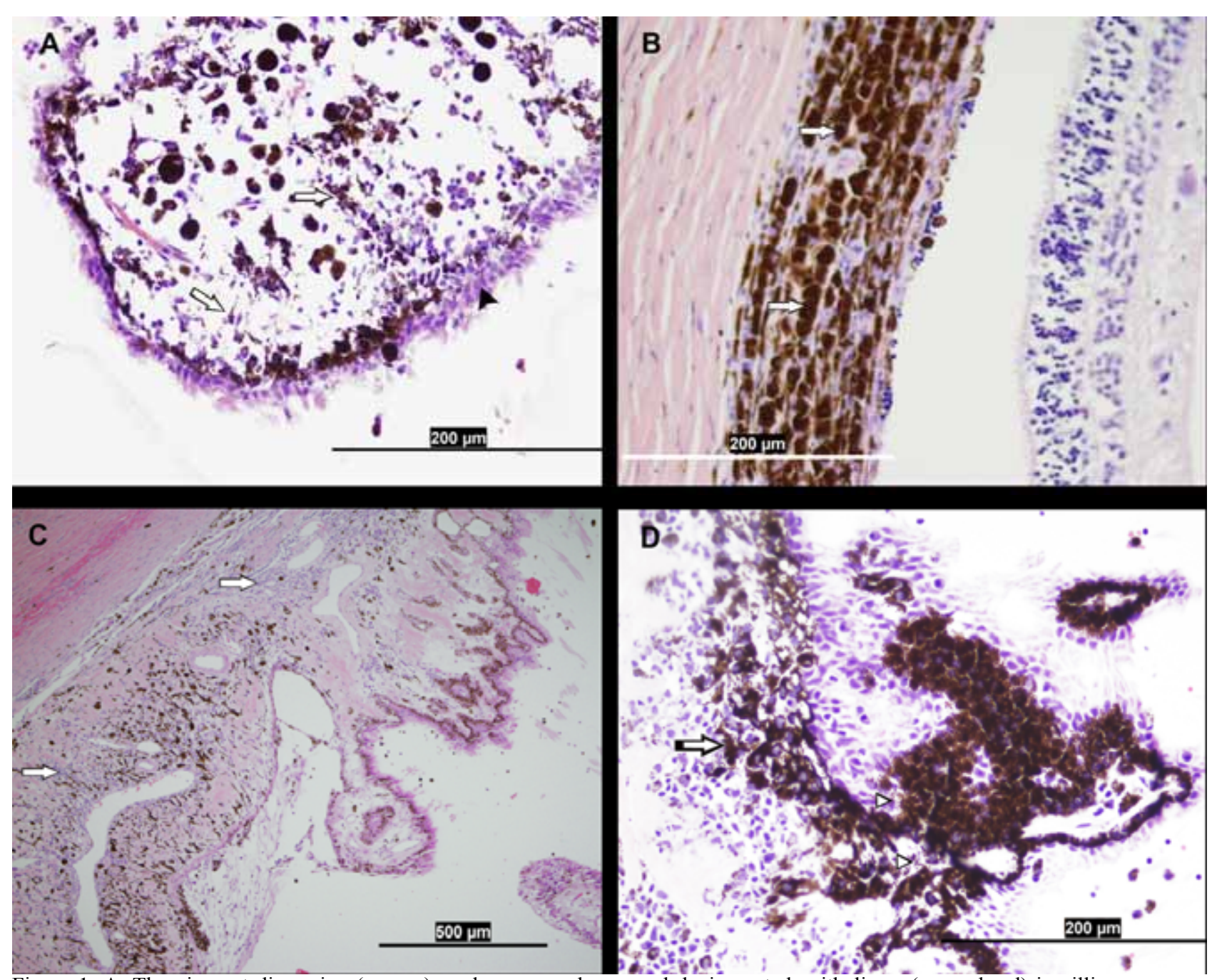

Figure 1. A. The pigment dispersion (arrows), melanomacrophages and depigmented epithelium (arrow head) in cilliary process, Hematoxyline and Eosin; B. Plump melanophages (arrows) clusturing interrupted by lymphocytic infiltrations in choroid, Hematoxyline and Eosin; C. Diffuse, chronic, moderate lymphoplasmacytic (arrows) cell infiltrations in iris base and ciliary body, Hematoxyline and Eosin; D. The accumulation of melanophages (arrow) and pigmentary incontinence (arrow head) in cilliary body and proceses Hematoxyline and Eosin.

Resim 1. A. Pigment dispersiyonu (oklar), melanomakrofajlar ve siliar proses epitelinde depigmentasyon (okbaşı), Hematoksilen ve Eozin; B. Koroid'de iri görünümlü melanofajlar (oklar) birimleri ve lenfositik infiltrasyonlar, Hematoksilen ve Eozin; C. Resim 1-C: İrisin tabanı ve siliar cisimcikte diffuz, kronik ve orta şiddette lenfoplazmasitik hücre infiltrasyonları (Oklar), Hematoksilen ve Eozin; D. Siliar cisimcik ve siliar proses'te melanofaj birikimleri (ok) ve pigment inkontinensi (ok baş1), Hematoksilen ve Eozin.

anterior uvea, whereas it was severe, diffuse and expanded choroid. Melanin containing aggregates of plump melanophages was more prominent in anterior uvea. There was chronic, diffuse, moderate pigmentary incontinence in choroid. There was necrosis in retinal ganglion cells characterized by reduced number of ganglion cells without inflammatory change. The optic nerve showed gliosis.

Case 3: Case 3 was 12-year-old, female-spayed Labrador retriever. She had history of sudden blindness. At initial presentation, bilateral uveitis was detected and the uveitis in the right eye responded well to medical therapy, but the intraocular pressure (IOP) and uveitis of the left eye did not change significantly. The IOP in right eye and left eye was $8 \mathrm{~mm} \mathrm{Hg}$ and $41 \mathrm{~mm} \mathrm{HG}$, respectively. The left eye was enucleated
Chronic, diffuse, moderate lymphoplasmacytic uveitis characterized by mononuclear cell infiltration within uveal stroma of the iris, ciliary body and throughout choroid was detected. The inflammatory cells in anterior uvea showed mainly perivascular location. Amongst the lymphoplasmacytic cells, there was a diffuse choroidal and anterior uveal accumulation of melanophages with pigmentary incontinence. There was small focus of retinal detachment adjacent to optic nerve head. There was iris bombé profile characterized by the pushed forward of iris leaflets and pupillary membrane and, chronic diffuse synechia. Retinal ganglion cells were decreased in number (secondary glaucoma).

Case 4: Case-4 was 7-year-old, female-spayed Labrador mixed breed. She was originally diagnosed with severe bilateral uveitis 2 years ago by the referring 
veterinarian. Both eyes were enucleated due to severe chronic poorly controlled glaucoma.

In right eye, throughout the uvea, especially prominent in the choroid, there were diminished numbers of pigmented cells with multifocal mild lymphocytic infiltrates present. Large, heavily pigmented melanophages were present in ciliary body, pars plicata and choroid. The retinal pigment epithelium lost the pigment and it became diffusely non-pigmented. Local melanophages and inflammatory infiltration in choroid was much less than other dogs. The corneal ulcer was present characterized by focally absence of epithelium in central cornea. There was a posterior synechia characterized by carpeting of anterior lens capsule by spindle cells.

In the left eye, there was melanophages in pars ciliaris, pars plicata and rarely choroid. The inflammatory cells were much less than the right eye. Although there was a difference in the severity of the lesions between the left eye and the right one, the general characteristics were the same. Additionally; pigmentary keratitis, preiridial fibrovascular membrane, optic gliosis, retro-corneal membrane and asteroid hyalosis were detected. Secondary glaucoma was characterized by diminished numbers of ganglion cells in the superior retina. And the inferior retina was reduced to a glial scar.

Case-5: Case 5 was a castrated-male, 3-year-old, Australian Shepherd dog. It was presented to referring veterinarian with bilateral uveitis and secondary glaucoma, however the inflammatory changes were inactive in the right eye. The duration of the problem was 3 weeks at first clinical examination. Intraocular pressure was $6 \mathrm{~mm}$ $\mathrm{Hg}$ and $48 \mathrm{mmHg}$ in the left and right eyes, respectively. After anti-inflammatory treatment, there was no recovery.

Histopathological examination revealed the uveitis characterized by circumferentially and moderately infiltrated with numerous lymphoplasmacytic cells, more severely in choroid, which is mildly expanded. Fewer macrophages were present within these inflammatory infiltrates. The infiltrate was generally perivascular location in iris and interstitial in iris base and ciliary body (Fig-1C). The depigmentation, pigment incontinence with melanophage infiltration were evident in iris and cilliary process (Fig-1D).

There was posterior synechia characterized by a thin pigmented spindle cell membrane carpeting the anterior lens capsule. Mild perivascular lymphoplasmacytic

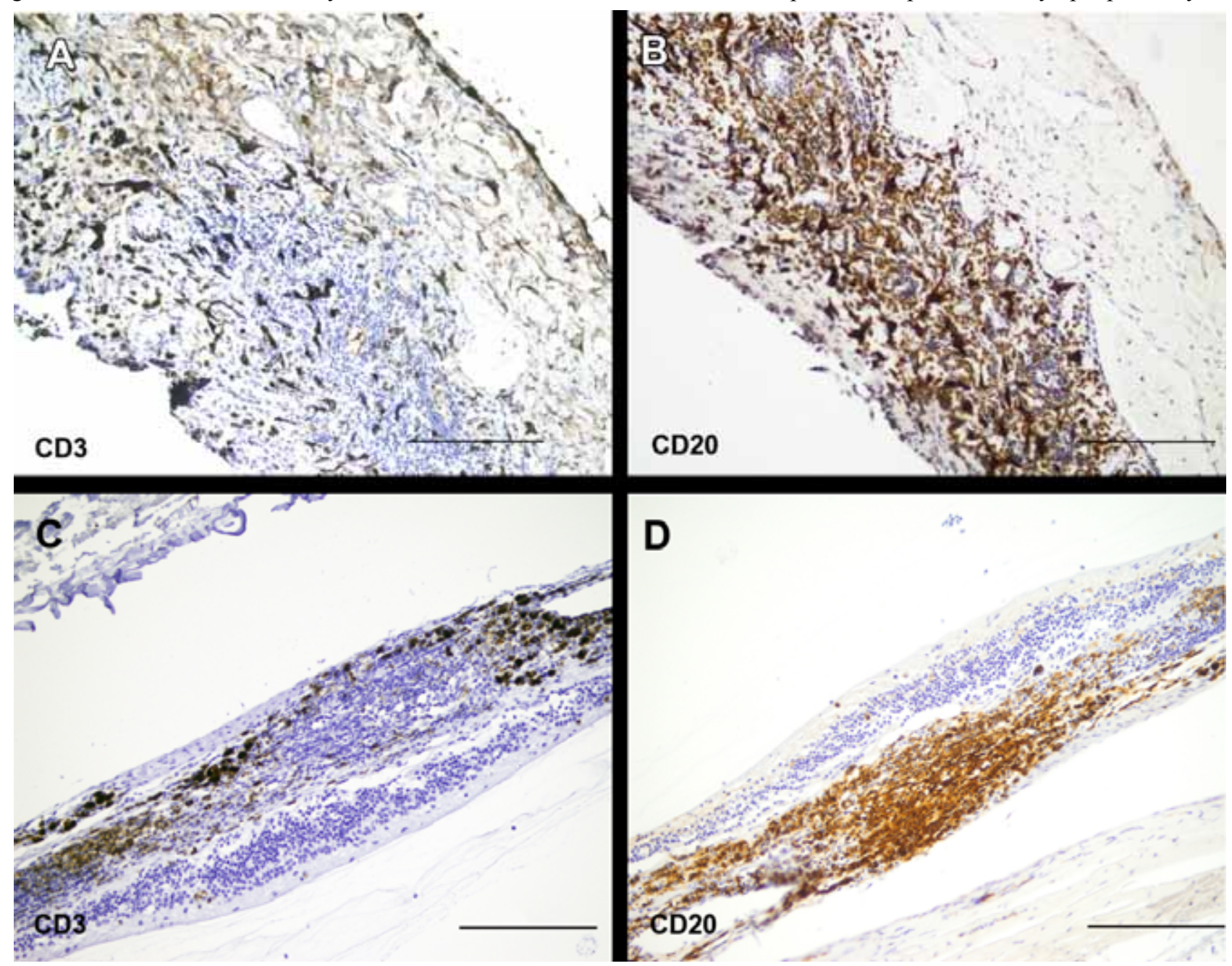

Figure 2. A-D. CD3-positive and CD20 positive cells in iris (A-B) and choroid (C-D), ABC method, Bar: $200 \mu \mathrm{m}$.

Resim 2. A-D. İris ve koroid'de CD3 ve CD20 pozitif lenfositler, ABC metod Bar: $200 \mu \mathrm{m}$. 
Table 2: Lymphocyte counts in the eyes.

Tablo 2: Gözlerde lenfosit sayıları.

\begin{tabular}{lcccc}
\hline & Iris & Cilliary Body Stroma & Cilliary Processes & Choroid \\
\hline $\mathrm{H}-\mathrm{E}$ & $161.90 \pm 97.97$ & $149.50 \pm 82.50$ & $26.25 \pm 16.46$ & $126.25 \pm 49.89$ \\
$\mathrm{CD} 20+$ & $134.65 \pm 90.97$ & $126.75 \pm 78.12$ & $18.00 \pm 12.90$ & $114.50 \pm 50.53$ \\
$\mathrm{CD} 20(\%$ of H\&E) & $83.00 \pm 9.42$ & $84.00 \pm 14.80$ & $68.00 \pm 6.55$ & $90.47 \pm 4.09$ \\
$\mathrm{CD} 3+$ & $27.25 \pm 11.44$ & $22.75 \pm 7.97$ & $8.25 \pm 4.65$ & $11.75 \pm 2.36$ \\
$\mathrm{CD} 3+(\%$ of H\&E) & $17.00 \pm 9.50$ & $16.00 \pm 14.74$ & $32.00 \pm 6.67$ & $9.53 \pm 3.67$ \\
$\mathrm{CD} 20+$ :CD3+ & $4.9 \pm 2.77$ & $5.25 \pm 3.78$ & $2.12 \pm 0.59$ & $9.49 \pm 5.66$ \\
\hline
\end{tabular}

infiltrates were present within episclera and orbit. The cornea showed moderate neovascularisation of the superficial two thirds of the peripheral corneal stroma, extending approximately $1 \mathrm{~mm}$ from the limbus. The superficial central and paracentral corneal stroma exhibits edema, with few scattered neutrophiles noted. Secondary glaucoma was diagnosed on the basis of necrosis in retinal ganglion cells on the superior aspect, with mild atrophy of the inner nuclear layer, and complete atrophy of all layers on inferior aspect (tapetal sparing). Focally, the superior retina showed absence of nuclear layers and only vessels and glia cells remain.

Immunohistochemical findings: The infiltrating lymphocytes consisted of predominantly B cells in iris, ciliary body, ciliary proceses and choroid (Table-2, Fig2A-D). Almost all of the perivascular lymphoid infiltrate were stained positive for CD20. CD3 positive T cells were scattered haphazardly amongst the outer layers of the infiltrate.

\section{Discussion and Conclusions:}

In this study, we have presented the occurrence of chronic or slowly progressing form of UDS in 5 dogs. Although bilateral granulomatous uveitis characterized by focal collection of epitheloid cells surrounded by the lymphocytes and pigment dispersion is the hallmark finding in UDS $(2-5,7,14)$, in the presented cases the uveitis was non-granulomatous and it was characterized by infiltration of lymphocytes, moderate plasma cells and few histiocytes and absence of epitheloid histiocytes. This result is compatible with those of long standing human cases with non-granulomatous inflammation (1, 5, 8, 9, 11). In humans; chronic cases have been characterized by lymphocytic uveitis $(8,9,11)$. VKH syndrome has been well-documented in humans with clinical features and from the initial to end, 4 stages have been described namely; predromal, acute uveitic, convalescent and chronic phases (14). The predromal stage is characterized by fever, nausea, neurologic signs and symptoms. The next stage is posterior uveitis phase which may last for 2 weeks. The next phase is anterior uveal involvement characterized by gradual uveal depigmentation. The convalescent phase may be interrupted by recurrent granulomatous anterior uveitis.
UDS in dogs typically begins with choroiditis and then proceeds to anterior uveitis (16).

Despite the usage of high-dosed oral and topical corticosteroids, the occurrence of more chronic or milder intraocular inflammation in our cases could be explained by breed or individual based factors. Similar to our finding, the occurrence of chronic intraocular inflammation is seen in $30 \%$ to $40 \%$ of Japanese human patients despite of corticosteroid treatment and explained by racedependent factors (10). Although VKH cases have been reported in mixed breeds, Australian shepherd and Dachshund dogs to the date, to the authors' knowledge, it was first described in the Labrador dogs in the present study. The mean age of involvement in earlier reports was 6.35 years ranging 1 to 11 years $(2-5,7,9-10,13$, 15). Similarly, the mean age averaged 6 years ranging 3 to 12 in our cases.

UDS related uveitis in our cases was complicated by secondary glaucoma, anterior synechia, iris bombé, posterior synechia and retinal detachment. The occurrence of these complications has been explained by the occurrence of chronic intraocular inflammation (14). The focal atrophy noted in retina is consistent with an ischemic injury of undetermined cause.

The chronicity of the lesions in humans was explained by the disappearance of choroidal melanocytes, consequently, a decreased stimulus to the entry of macrophages into the lesions $(8,14)$. Similar to this comment, in the case 4, choroidal melanocytes were decreased in number and the inflammation in the choroid was mild in severity.

Immunohistochemically; lymphocytic infiltrate showed the marked predominance of B cells in all cases. This finding is completely consistent with an earlier study in the naturally occurring UDS in two dogs showing granulomatous panuveitis together with B lymphocyte is predominance (3), whereas VKH syndrome in humans which is a $\mathrm{T}$ lymphocyte mediated autoimmune process and approximately $70 \%$ of the lymphocytes are $\mathrm{T}$ cells $(12,14)$. Our results support two earlier theories that UDS has a different pathogenesis from VKH in humans and UDS might not be a good model for human VKH (3, 7). 
In conclusion, we believe that the milder or chronic and the more typical and more robust form of uveodermatologic syndrome are part of a spectrum of disorders caused by hypersensitivity of the melanin or melanocytic protein mediated by humoral immune response. The reason for more chronic or milder lesions in presented cases could be explained by corticosteroid drug usage, decreased melanocyte number or individual dependent factors.

\section{References}

1. Beniz J, DJ Forster, JS Lean, S John, RE Smith, NA Ra (1991): Variations in clinical features of the VogtKoyanagi-Harada syndrome. Retina, 11, 275-280.

2. Blackwood ES, PK Barrie, EC Plummer, D Taylor, CE Nunnery, DJ Seltzer, G Ben-Shlomo, DE Brooks (2011): Uveodermatologic Syndrome in a Rat Terier. J Am Anim Hosp. Assoc, 47, 56-63.

3. Carter W, S Crispib, D Gould, M Day (2005): An immunohistochemical study of uveodermatologic syndrome in two Japanese Akita dogs. Vet Ophtalmol, 8, 17-24.

4. Catoi C, M Zotuscu, AI Baba, A Gal, I Rus (2007): Vogt-Koyanagi-Harada like Syndrome in a German Shepherd dog. Bulletin USAMV, 64, 1-2.

5. Cotrrell BD, KC Barnet (1987): Harada's disease in Japanese Akita. J Small Anim Pract, 28, 517-521.

6. Dubielzig RR, KL Ketrig, DM Albert, G McLenan (2010): Veterinary Ocular Pathology, The uvea, A Comparative Review, Saunders Elsevier, 260-263, 279.

7. Godoy CAL, AMV Safatle, AL Teixeira, MSB Souza, PSM Barros (2003): Uveodermatologic Syndrome in Cocker-Poodle Mixed Breed Dog. Arc Vet Sci, 8, 20-33.

8. Inomata H, T Sakamoto (1990): Immunohistochemical studies of Vogt-Koyanagi-Harada disease with sunset sky fundus. Current Eye Research, 9, 35-40.
9. Kern TJ, DK Walton, RC Riis (1985): Uveitis associated with poliosis and vitilogo in six dogs. J Am Vet Assoc, 187, 408-414.

10. Lindley JL, TR Boosinger, NR Cox (1990): Ocular histopathology of Vogt-Koyanagi-Harada-like syndrome in an Akita dog. Vet Pathol, 27, 294-296.

11 Laus JL, MG Sousa, VP Cabral, FV Mamede, M Tunicci-Costa (2004): Uveodermatologic syndrom in a Brazilian Fila dog. Vet Ophtalmol, 7, 193-196.

12. Morgan RV (1989): Vogt-Koyagani-Harada syndrome in humans and dogs. Comp Cont Edu Prac Vet, 11, 12111218.

13 Pye H. (2009):Uveodermatologic syndrome in an Akita. Can Vet J, 50, 861-864.

14. Rao NA (2007): Pathology of Vogt-Koyagani-Harada disease. Int Ophthalmol, 27, 81-85.

15. Sigle KJ, GJ McLellan, J.S Haynes,., Myers, R.K., Betts, D.M (2006): Unilateral uveitis in a dog with uveodermatologic syndrome. J Am Vet Med Assoc, 228, 545-548.

16. Yamaki K, N Takiyami, N Itho, N Mizuki, M Seiya, W Sinsuke, K Hayakawa, T Kotani (2005): Experimentally induced Vogt-Koyagani-Harada disease in two Akita dogs. Exp Eye Res, 80, 273-280.

Geliş tarihi: 12.09.2013 / Kabul tarihi: 26.02.2014

Address for correspondence:

Dr. Yesari Eröksüz

Firat University,

Veterinary Medical School,

Pathology Department,

Elazı̆g/TURKEY 